\title{
Review of Teachers' Technological Pedagogical Content Knowledge (TPACK) in China
}

\author{
Wei Zhang1, Junhong Tang2 \\ ${ }^{1}$ Educational Administration Department, Baoding Technical College of Electric Power, Baoding, China \\ ${ }^{2}$ College of Foreign Language Education and International Business, Baoding University, Baoding, China \\ Email: jessytang99@163.com
}

How to cite this paper: Zhang, W., \& Tang, J. H. (2021). Review of Teachers' Technological Pedagogical Content Knowledge (TPACK) in China. Creative Education, 12, 1726-1743. https://doi.org/10.4236/ce.2021.127131

Received: June 7, 2021

Accepted: July 25, 2021

Published: July 28, 2021

Copyright (c) 2021 by author(s) and Scientific Research Publishing Inc. This work is licensed under the Creative Commons Attribution International License (CC BY 4.0).

http://creativecommons.org/licenses/by/4.0/

\begin{abstract}
In this study, 169 journal papers retrieved from "China Article Full Text Database" of China National Knowledge Infrastructure (CNKI) were analyzed as the samples in this study. Quantitative visual statistic analyses were conducted in terms of annual volume and the top five contribution institutions to offer some basic information of teachers' TPACK study in China. What's more, qualitative deep content analyses were conducted through four research themes including "Introduction of Foreign Study on Teachers' TPACK" "Pre-Service Teachers' TPACK Level and Development Paths" "Development Paths of In-Service Teachers' TPACK" and "Teachers' TPACK Study of Specific Subjects", which intends to show deeper analyses of teachers' TPACK study in China by qualitative deep content analysis.
\end{abstract}

\section{Keywords}

TPACK, Journal Papers, Current Situation, Research Themes, Reflection and Outlook

\section{Introduction of TPACK}

Technological pedagogical content knowledge (TPACK) conforms to the requirements for teachers' professional ability in China in the information era. It also offers a very useful framework for Chinese teachers' development. So, in this study, 169 articles were analyzed in terms of annual volume, main research institutions and four research themes to offer reference for researchers and educators to develop teachers' TPACK more efficiently.

\section{The Concept of TPACK}

Matthew J. Koehler and Punya Mishra put forward the concept of TPCK 
(Koehler \& Mishra, 2005) on the basis of Shulman's PCK construct (Shulman, 1986; Shulman, 1987). In 2007, Thompson and Mishra changed TPCK into TPACK. In 2008, contexts were introduced into TPACK as the eighth element. So far, TPACK framework contains three core elements, content knowledge (CK), pedagogical knowledge (PK) and technology knowledge (TK), four interacted knowledge, pedagogical content knowledge (PCK), technological content knowledge (TCK), technological pedagogical knowledge (TPK) and technological pedagogical content knowledge (TPACK), and context (Koehler \& Mishra, 2008), which can be shown in Figure 1.

Specifically, three major knowledge components form the foundation of the TPACK framework and four components in the TPACK framework address how these three bodies of knowledge interact, constrain, and afford each other as follows (Koehler, Mishra, Kereluik, Shin, \& Graham, 2014).

- CK refers to any subject-matter knowledge that a teacher is responsible for teaching.

- PK refers to teacher knowledge about a variety of instructional practices, strategies, and methods to promote students' learning.

- TK refers to teacher knowledge about traditional and new technologies that can be integrated into curriculum.

- TCK refers to knowledge of the reciprocal relationship between technology and content. Disciplinary knowledge is often defined and constrained by

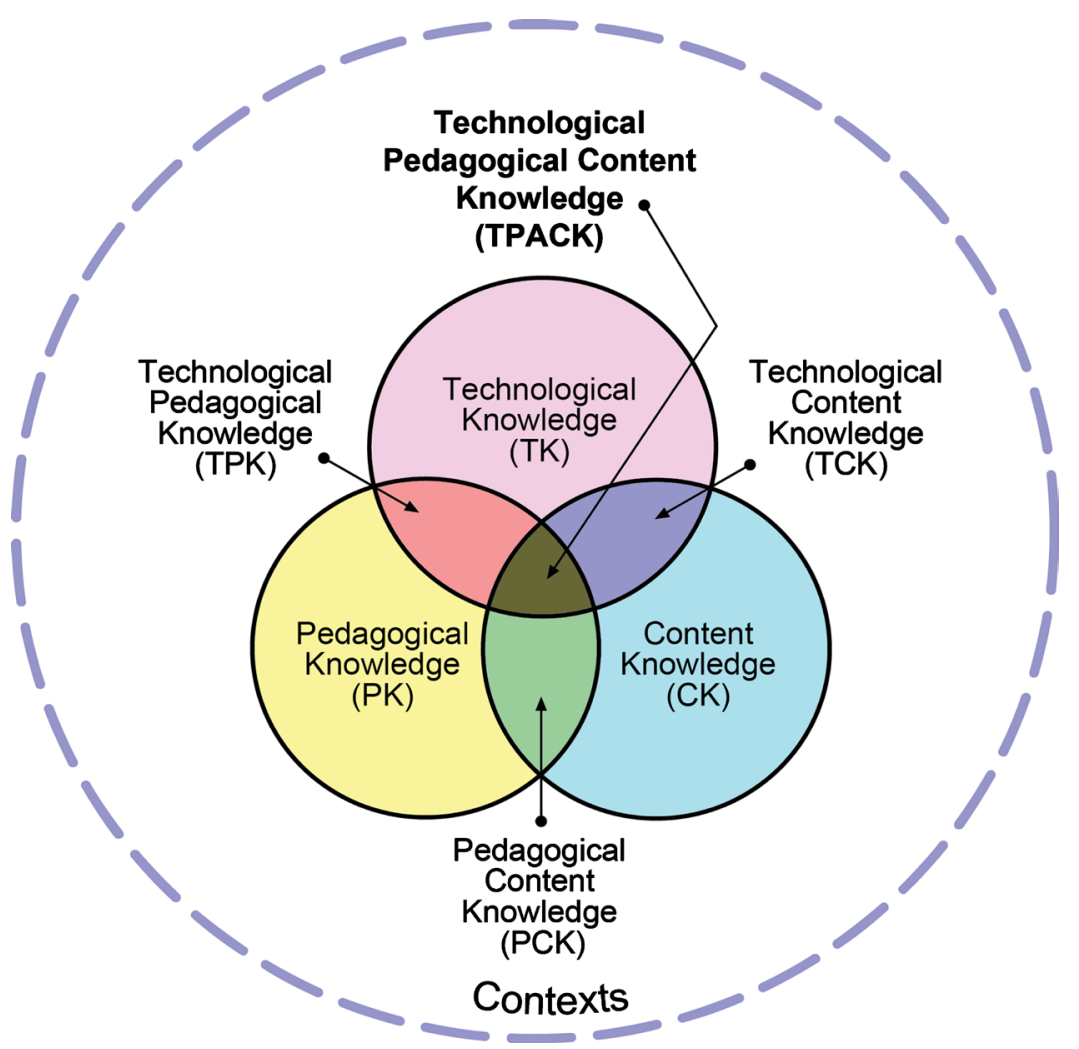

The source of the image is attributed as http://tpack.org.

Figure 1. The technological pedagogical content knowledge framework. 
technologies and their representational and functional capabilities.

- PCK is to Shulman's (1986) notion of "an understanding of how particular topics, problems, or issues are organized, represented, and adapted to the diverse interests and abilities of learners, and presented for instruction" (p. 8).

- TCK refers to an understanding of technology can constrain and afford specific pedagogical practices.

- TPACK refers to knowledge about the complex relations among technology, pedagogy, and content that enable teachers to develop appropriate and context-specific teaching strategies.

\section{The Importance of Teachers' TPACK in China}

In the information era, teachers' TPACK development has become not only a requirement but also a declaration in China (Wu, 2014). Early in March, 2012, The Ten Year Development Plan of Educational Informatization (2011-2020) issued by Ministry of Education of the People's Republic of China stated clearly that educational modernization came from educational information and technology. In May, 2014, The Standard of Primary and Secondary School Teachers' Information Technology Application Ability (Trial Implementation) issued by Ministry of Education of the People's Republic of China also emphasized that it was the basic requirement for teachers to use information technology to optimize classroom teaching and change learning mode in the information age. In January, 2018, the Central Committee of the Communist Party of China and the State Council issued The Opinions on Comprehensively Deepening the Reform of the Construction of Teachers in the New Era clearly put forward that teachers should adapt to information technology actively. The latest Educational Modernization of China 2035 issued by the Central Committee of the Communist Party of China and the State Council in February, 2019 advised strongly using modern technology to accelerate the reform of education mode.

It has become a hot topic in the field of education to improve teachers' teaching ability by using modern information technology (Bai, 2017). The knowledge possessed by teachers is the basis for teachers to carry out teaching activities. Its composition and structure will directly affect teachers' teaching behavior and students' learning outcomes (Liu, 2019). In the information and technology era, TPACK is the essential knowledge and key factor for teachers to integrate technology into teaching (AACTE Committee on Innovation and Technology, 2008). Teachers are the real "magicians" in the integration process of technology and curriculum (Wu, 2017).

Therefore, this study aims to offer a general understanding of current teachers' TPACK study in China by using statistic and content analyses, make some reflections and outlook for teachers' TPACK future study.

\section{Methodology}

In this study, we adopted a statistical visual analysis and a deep content analysis 
with the samples that we retrieved from China Journal Full Text Database of China National Knowledge Infrastructure (CNKI) according to certain inclusion criteria.

\subsection{Inclusion Criteria}

Here are the reasons for the inclusion criteria. First of all, China Journal Full Text Database of CNKI is a full-text database of Chinese high-quality journals with complete resources and dynamic updates. Moreover, Peking University Core Periodicals and Periodicals of Chinese Social Sciences Citation Index (CSSCI) are the two kinds of core periodicals of social sciences in China. In other words, articles in these two kinds of periodicals represent highest quality and latest topics to a great extent. In addition, "TPACK" is the acronym of technological pedagogical content knowledge and "TPACK" is originally called "TPCK" before 2007.

With regards to the above three reasons, the journal articles about teachers' TPACK study retrieved from China Journal Full Text Database of CNKI can reflect current teachers' TPACK study situation to a certain extent and offer some hints to predict the future research trend of teachers' TPACK study, so the following four inclusion criteria items were utilized in the retrieving procedure in order to get the target research samples.

First, articles in China Journal Full Text Database of CNKI.

Second, articles published in Peking University Core Periodicals and Periodicals of Chinese Social Sciences Citation Index.

Third, the title of the article must include "TPACK" or "TPCK" or "Technological Pedagogical Content Knowledge".

Fourth, no time limit for publication.

\subsection{Retrieve Procedure}

In accordance with the above inclusion criteria, the retrieving procedure is the following six steps. First, selected China Journal Full Text Database of CNKI. Second, selected "basic science", "philosophy and humanities", "Social science I" and "Social Science II" in the classified catalogue. Third, chose "topic" in the "search criteria" and entered into "TPACK" or "TPCK" or "Chinese characters for technological pedagogical content knowledge". Fourth, adopted exact matching. Fifth, selected "Core Journals (it refers to Peking University Core Periodicals here)" and "CSSCI" as the source category. Sixth, did not fix publication year parameter for all articles in the database meeting the criteria.

\subsection{Retrieve Result}

The retrieval date is January $20^{\text {th }}, 2020$. As a result, we retrieved 169 journal papers related to our topic of interest with these keywords: "TPACK" or "TPCK" or "technological pedagogical content knowledge". The earliest one was published on April $5^{\text {th }}, 2008$ and the latest one was published on December $2^{\text {nd }}, 2019$. 
So 169 journal papers published in China Journal Full Text Database of CNKI from April 2008 to December 2019 were used as research samples for statistical visual analysis and a deep content analysis in this study.

\section{Analysis on Teachers' TPACK Study Domains in China}

In this study, 169 journal papers were analyzed by means of quantitative statistical analysis and qualitative deep content analysis in terms of the following four domains. They were annual volume, main research institutions and research themes in teachers' TPACK development in China. The former two domains, annual volume and the top five contribution institutions of TPACK journal papers, offered some basic information of teachers' TPACK study in China by statistical visual analysis. The latter domain of research themes including "Introduction of Foreign Study on Teachers' TPACK" "Pre-Service Teachers' TPACK Level and Development Paths" "Development Paths of In-Service Teachers' TPACK" “Teachers' TPACK Study of Specific Subjects", intends to show deeper analyses of teachers' TPACK study in China by qualitative deep content analysis.

\subsection{Annual Volume of Teachers' TPACK Journal Papers}

The annual distribution of the 169 research samples from April 2008 to December 2019 was shown in Figure 2. From 2008 to 2019, the annual volume of teachers TPACK journal papers was numbered as 1, 0, 1, 3, 9, 16, 18, 32, 26, 25, 19 and 19 respectively, which showed the popularity and importance of teachers' TPACK in China. From 2010 to 2015, the number of published papers in the field of teachers' TPACK continued to rise and it reached its peak in 2015 with an annual volume of 32 articles. From 2015 to 2018, the number of published articles dropped from 32 to 19 continuously. The number of published papers in 2019 was the same as in 2018 with the annual volume of 19 journal papers and it showed a decline almost half of that in 2015.

\subsection{The Top Five Contribution Institutions of Teachers' TPACK Journal Papers}

According to statistical visualization analysis of CNKI, the top five institutions in terms of the number of published papers in the field of teachers' TPACK study were all normal universities. They were Beijing Normal University, Northeast

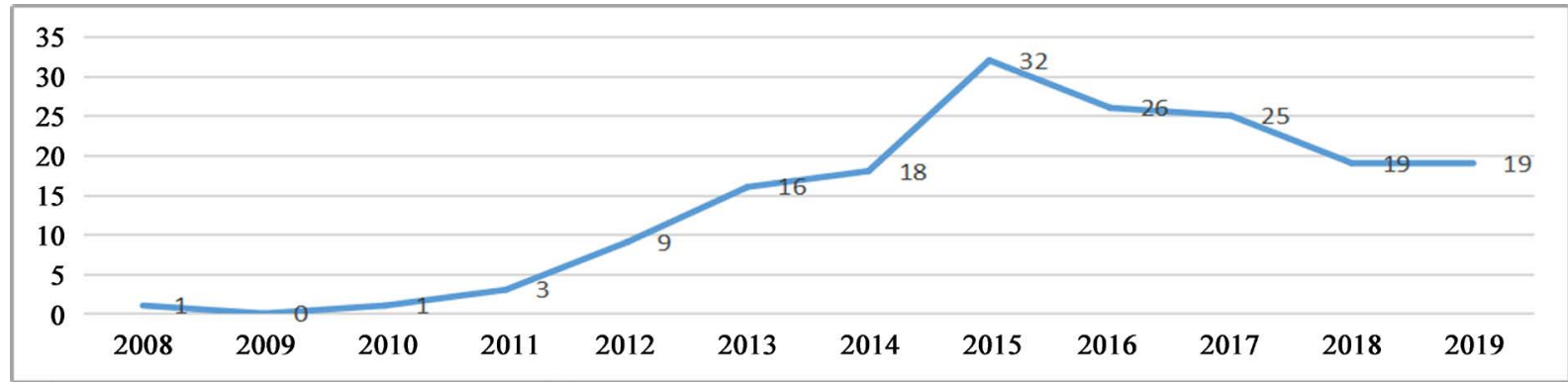

Figure 2. Annual volume of the 169 samples from 2008 to 2019. 
Normal University, South China Normal University, East China Normal University and Qufu Normal University. The numbers of journal papers they contributed to were 14, 12,11, 10 and 10 respectively, which can be shown in Figure 3. Altogether 57 journal papers of the total 169 samples were contributed by the top five institutions and it took up 33.73\%.

Qufu Normal University is in the charge of Shandong Province and South China Normal University is in the charge of Guangdong Province. The other three normal universities are all in the charge of Ministry of Education of the People's Republic of China. To some extent, it showed that teachers' TPACK study had earned attention of national and provincial normal universities, but less local normal universities which are in the charge of municipal government and occupy a large number paid attention to teachers' TPACK study.

However, local normal universities are supposed to keep up with the pace of the information and technology era when teachers' TPACK is not only a mandate but also a manifesto (AACTE Committee on Innovation and Technology, 2008). They should begin to pay much more attention to teachers' TPACK study in order to serve for their local education respectively, which will be further explained in the latter reflection and outlook section.

\subsection{Research Themes of Teachers' TPACK Study in China}

We found there were mainly four research themes of teachers' TPACK study in China after a qualitative deep content analysis of the 169 journal papers retrieved from China Journal Full Text Database of CNKI. They were "introduction of foreign study on teachers' TPACK”, "pre-service teachers' TPACK development paths", "in-service teachers' TPACK development paths" and "teachers' TPACK study of specific subjects", which would be expounded in the sub-sections.

\subsubsection{Introduction of Foreign Study on Teachers' TPACK}

After a deep reading of the 169 journal papers, we found that 14 of the 169 samples are mainly about the introduction of foreign study on teachers' TPACK.
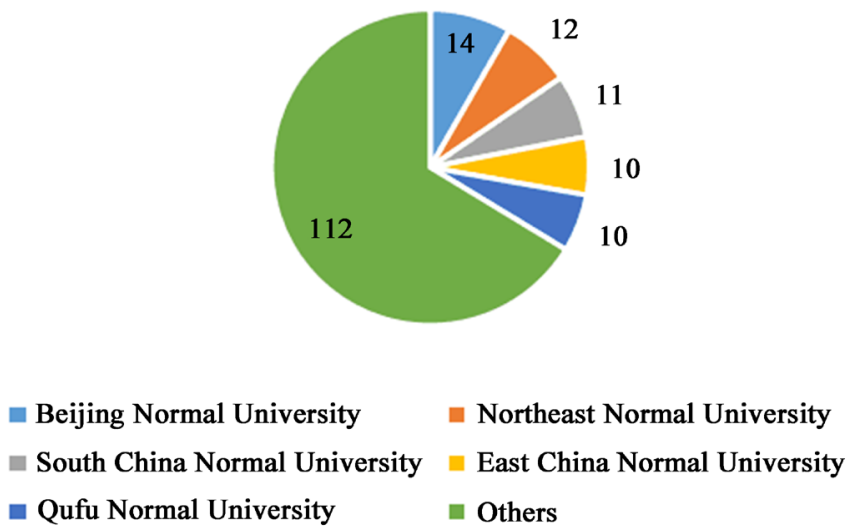

Figure 3. The top five contribution institutions and the numbers of their published papers. 
The methods adopted were 1) we read and analyzed the 14 journal papers in detail and 2) classified them into four sub-themes: introduction of TPACK frameworks and schools, development paths, measurement methods and others including general analyses and an interview report. The detailed information of the introductory journal papers can be shown in Table 1 .

\subsubsection{Pre-Service Teachers' TPACK Level and Development Paths}

The quality and professional ability of pre-service teachers are closely related to the construction of Chinese teachers' capabilities (Wang \& Wu, 2018). Developing pre-service teachers' application ability of information technology in practice plays a critical role in cultivating a group of qualified primary and secondary school teachers in the information age (Zheng \& Zhang, 2019). TPACK provides a new point for pre-service teachers' education and how to promote pre-service teachers' TPACK has become an urgent and important issue. We found that Chinese researchers had done some investigations into the present level and the development paths of pre-service teachers' TPACK.

In this study, the journal papers of pre-service teachers' TPACK study were retrieved by the following method. First, we used the term "Normal Students" to search in the titles of the 169 journal papers retrieved from China Journal Full Text Database of CNKI and got 18 journal papers. In other words, 18 of the 169 titles of the journal papers included the term "Normal Students". Second, we used the term "Pre-Service Teachers" to search again in the rest of the 151 titles of the journal papers and retrieved another 10 journal papers. Third, we made a deep reading of the left 141 journal papers and figured out another two journal papers related to pre-service teachers' TPACK education. One is about masters' TPACK education in Geography and the other is about pre-service teachers TPACK in Chemistry teaching. Altogether we found 30 journal papers related to pre-service teachers' TPACK education. After a detailed content analysis, we found "normal students" and "pre-service teachers" referred to the same subject, the would-be teachers in normal universities, so we call both "normal students" and "pre-service teachers" as "pre-service teachers" for convenience and consistency with the latter "in-service teachers".

\section{1) Present Level of Pre-Service Teachers' TPACK}

Chinese researchers found the present TPACK level of pre-service teachers is not high. After an empirical study of 463 pre-service teachers of general education studies, Dong Yan, Sang Guoyuan and Cai Jingxin (2014) came to the conclusion that the TPACK level of pre-service teachers was comparatively low. Wang Lizhen and Fu Liping (2015) also came to the conclusion that the TPACK level of Chinese pre-service teachers was not very optimistic. Some other researchers also made some research works on the present TPACK level of pre-service teachers of specific subjects. For example, the TPACK level of pre-service mathematical teachers was low, especially in terms of the integrated factors of TPACK (Zhang \& Wang, 2016) and the TPACK level of pre-service 
Table 1. Four sub-themes of introduction of foreign study on teachers' TPACK.

\begin{tabular}{|c|c|c|c|c|c|}
\hline Numbers & Sub-Themes & $\begin{array}{l}\text { Published } \\
\text { Year }\end{array}$ & Titles & Author(s) & Database(s) \\
\hline \multirow{4}{*}{1} & \multirow{2}{*}{ Frameworks } & 2015 & $\begin{array}{l}\text { Study on Current Situation and Development Trend } \\
\text { of Teachers' TPACK }\end{array}$ & $\begin{array}{l}\text { Ning Lianhua } \\
\text { \& Xiang Kun }\end{array}$ & $\times$ \\
\hline & & 2012 & $\begin{array}{l}\text { Literature Review on Technological Pedagogical } \\
\text { Content Knowledge }\end{array}$ & Yuan Zhiqiang & $x$ \\
\hline & \multirow[b]{2}{*}{ Schools } & 2015 & $\begin{array}{l}\text { Research on Technological Pedagogical Content } \\
\text { Knowledge (TPACK): Progress and Trends }\end{array}$ & $\begin{array}{l}\text { Cai Jingxin } \\
\text { \& Deng Feng }\end{array}$ & $x$ \\
\hline & & 2014 & Challenges Facing TPACK Theoretical Research & $\begin{array}{l}\text { Yu Yong, Bu } \\
\text { Juanjuan \& } \\
\text { Zhang Hai }\end{array}$ & Web of Science (2006-2013) \\
\hline \multirow{5}{*}{2} & \multirow{5}{*}{$\begin{array}{l}\text { Development } \\
\text { Paths }\end{array}$} & 2015 & $\begin{array}{l}\text { Study on Current Situation and Development Trend } \\
\text { of Teachers' TPACK }\end{array}$ & $\begin{array}{l}\text { Ning Lianhua } \\
\text { \& Xiang Kun }\end{array}$ & $x$ \\
\hline & & 2014 & $\begin{array}{l}\text { Inspiration of Foreign Teachers TPACK } \\
\text { Development Paths }\end{array}$ & Wu Huanqing & $\begin{array}{l}\text { CNKI, ProQuest, Springer-Link, } \\
\text { Wiley Online Library (2005-2011) }\end{array}$ \\
\hline & & 2012 & $\begin{array}{l}\text { Literature Review on Technological Pedagogical } \\
\text { Content Knowledge }\end{array}$ & Yuan Zhiqiang & $x$ \\
\hline & & $2012 \mathrm{a}$ & $\begin{array}{l}\text { TPACK-New Paths and Methods of American } \\
\text { integration between curriculum and technology }\end{array}$ & He Kekang & $x$ \\
\hline & & $2012 b$ & $\begin{array}{l}\text { TPACK-New Paths and Methods of American } \\
\text { integration between curriculum and technology }\end{array}$ & He Kekang & $x$ \\
\hline \multirow{3}{*}{3} & \multirow{3}{*}{$\begin{array}{l}\text { Measurement } \\
\text { Methods }\end{array}$} & 2016 & $\begin{array}{l}\text { Research Status and Thinking of TPACK Measure } \\
\text { Methods at Home and Abroad }\end{array}$ & $\begin{array}{l}\text { Gu Yanxia } \\
\text { \& Qian Xuyuan }\end{array}$ & $\times$ \\
\hline & & 2013 & $\begin{array}{l}\text { Reviews and Enlightenment of Foreign } \\
\text { Measurement on Technological Pedagogical } \\
\text { Content Knowledge }\end{array}$ & $\begin{array}{l}\text { Xu Peng, } \\
\text { Liu Yanhua, } \\
\text { Wang Yining } \\
\text { \& Zhang Hai }\end{array}$ & $x$ \\
\hline & & $2017 b$ & $\begin{array}{l}\text { Reviews and Enlightenment of the American New } \\
\text { Evaluation Tools on Teachers' Technological } \\
\text { Pedagogical Content Knowledge }\end{array}$ & Huang Fuqian & $\times$ \\
\hline \multirow{4}{*}{4} & \multirow{3}{*}{$\begin{array}{l}\text { General } \\
\text { Analysis }\end{array}$} & 2018 & $\begin{array}{l}\text { Knowledge Mapping Analysis on English TPACK } \\
\text { journal papers: Origin and Development }\end{array}$ & $\begin{array}{l}\text { Deng Guomin, } \\
\text { Li Hui, } \\
\text { \& Luo Min }\end{array}$ & $\begin{array}{l}\text { Web of Science(No publish time } \\
\text { limit) }\end{array}$ \\
\hline & & 2013 & Foreign TPACK Study and Enlightenment & $\begin{array}{l}\text { Xu Peng, } \\
\text { Zhang Hai, } \\
\text { Wang Yining } \\
\text { \& Liu Yanhua }\end{array}$ & $\begin{array}{l}\text { Education Resources Information } \\
\text { Center(ERIC), SCOPUS, Wiley, } \\
\text { Web of Science, Springer Link } \\
\text { (2005-2013), TPACK Newsletters } \\
(2009.01-2013.05)\end{array}$ \\
\hline & & 2015 & $\begin{array}{l}\text { A Review on Theory Development and Practical } \\
\text { Implications of Technological Pedagogical Content } \\
\text { Knowledge ( TPACK): 2005-2014 }\end{array}$ & $\begin{array}{l}\text { Zhang Zhe, } \\
\text { Zhang Hai } \\
\text { \& Wang Yining }\end{array}$ & $\begin{array}{l}\text { Web of Science, Scopus } \\
(2005-2014)\end{array}$ \\
\hline & $\begin{array}{l}\text { Interview } \\
\text { Report }\end{array}$ & 2013 & $\begin{array}{l}\text { TPACK Latest Understanding about ICT for Subject } \\
\text { Teaching and Learning: An Interview with } \\
\text { Professor Matthew Koehler }\end{array}$ & $\begin{array}{l}\text { Zhang Baohui } \\
\text { \& Zhang Jing }\end{array}$ & $x$ \\
\hline
\end{tabular}

chemistry teachers was maintained at a low level (Wei \& Zhou, 2015).

2) TPACK Development Strategies of Pre-Service Teachers

In order to promote pre-service teachers TPACK effectively, researchers put 
forward different development strategies. Some researchers explored TPACK development strategies with reference to "learning by design". They preferably suggested this strategy because of the efficiency of "learning by design" by group teaching experiment (Zheng \& Zhang, 2019), searched how to use technology to carry out science teaching and pursued the synergistic effect between learning theory and technology (Huang, 2017a) and designed micro-courses to carry out teaching experiments (Ma \& Liu 2018; Zhan \& Ren, 2011). Other researchers introduced construction of waterfall model for pre-service teachers' TPACK capacity building (Nie, 2017), TPACK Game (Huang, Jiang, \& Zhang, 2017), and so forth to promote the development of pre-service teachers TPACK.

\section{3) Curriculum Integration for Pre-Service Teachers' TPACK Cultivation}

The construction of pre-service teachers' education curriculum system is one of the key factors to assure the quality of teacher education and professional development, so optimizing the curriculum of pre-service teachers education is an important way to promote teachers' TPACK. Some researchers put forward that normal universities should implement integrated curriculum to promote pre-service teachers' TPACK. Liu Zhe (2016) carried out pre-service teachers' TPACK study by integrating curriculum on the basis of empirical analysis of structural equation model (Liu, 2016). Some other researchers also suggested integrating technology course with the course of teaching theory and methods of specific subjects (Zhang, Zhang, Liu, \& Wang, 2015), strengthening the integration between different teachers' courses and making different courses contents from scattered and isolated to integrated and connected (Zhang \& Yang, 2016).

In addition, some other researchers made some explorations in curriculum integration of specific subjects. Deng Feng, Chen Lingling, Li Ailing and Wu Songfa (2018) advocated to guide pre-service teachers to think and reflect on the integration of information technology and Chemistry teaching (Deng, Chen, Li, \& Wu, 2018). Dai Jin, Ren Yanan and Li Weihan (2018) also suggested the design of pre-service Biology teachers' curriculum should pay attention to two-dimensional integrated knowledge (Dai, Ren, \& Li, 2018).

In summary, researchers in China have been searching how to integrate different courses to develop pre-service teachers' TPACK.

4) Diversified Teaching Practice for Pre-Service Teachers' TPACK Development

TPACK is a kind of practical knowledge. It must be gradually cultivated in long-term learning and practice (Zhang \& Yang, 2016). Chinese researchers also proposed to strengthen teaching practice to ensure the development of pre-service teachers' TPACK. They suggested putting more emphasis on teaching practice and changing the relationship between theory and practice from separation to combination. For example, Huang Xuemei (2018) proposed promoting diversified teaching practice for pre-service teachers to accumulate experience to develop their TPACK in practice (Huang, 2018). Wang Lizhen and Fu Liping (2015) also advocated strengthening teaching practice and reconstructing 
education mode to develop pre-service teachers' TPACK (Wang \& Fu, 2015).

\subsubsection{Development Paths of In-Service Teachers' TPACK}

We found there were three main paths for in-service teachers' TPACK development after a deep content analysis of the rest of the 125 journal papers. The three main paths are promoting teachers' autonomous development, building learning community and establishing and improving guarantee mechanism.

\section{1) Promoting In-Service Teachers' Autonomous Development}

Teachers' autonomous development referred to awakening and arousing teachers' potential creativity and reflecting on their teaching practice actively and continuously to reconstruct their TPACK (Zhang \& Liu, 2015). Such autonomous development paths as promoting teachers' awareness of autonomous development (Shang \& Cheng, 2017), stimulating teachers' intrinsic potentiality and enhancing the ability of teachers' reflection (Dong, He, Sikandier, \& Xu, 2019) had been put forward in China.

TPACK was a new requirement for teachers' knowledge structure in the era of information technology. Teaching activity was no longer a simple process of teachers' lecturing and students' listening, but a process of analysis, design, practice and reflection. The teacher was not a fixed teacher any longer but a dynamic reflective practitioner (Liu, 2019). Reflection should run through the whole process of teaching practice and play a key role in the development of teachers' TPACK (Liuhuang \& Huang, 2005; Xie, Song, \& Liu, 2008).

If a teacher had been only satisfied with the daily teaching process and had not thought deeply about his own teaching practice, no matter how long his actual teaching age is, he would have only been a teacher and it was difficult for him or her to become an excellent teacher (Yan, Hui, \& Ning, 2018). An excellent teacher was supposed to constantly revise and modify his or her understanding and practical application of the subject teaching content, teaching methods and technology for flexible and creative usage of TPACK in a comprehensive way. This was because it was the highest realm for a teacher to choose appropriate education technology to design teaching content and teaching methods that meet the students' learning context (Shu, 2014; Ruan \& Yang, 2014).

The development of teachers' TPACK depended on Teachers' reflection ability, which was also an important factor to ensure teachers' continuous improvement and development in teaching practice ( $\mathrm{Wu}, \mathrm{Yu}, \& \mathrm{Ma}, 2014)$.

\section{2) Building Collaborative TPACK Learning Communities for Teachers}

Social constructivists hold that "social interaction" is the basic form of individual learning. In other words, social individuals must interact with others to complete various cognitive activities (Zhang \& Liu, 2015). Shulman and Hammerness $\mathrm{K}$ also argued that community is a key element in teachers' learning framework (Shulman, 2004; Hammerness, 2005). From the perspective of social culture, Kelly Peter put forward that an important principle to develop teachers' learning is to promote teachers to develop teaching expertise in the complex network of collaborative learning (Kelly, 2006). 
Chinese researchers also put forward building collaborative communities to develop teachers' TPACK. Early in 2013, Li Haifeng advocated building TPACK curriculum research community (Li, 2013). Wu Huanqing put forward Collaborative Construction Model for teacher's TPACK development in 2014 (Wu, 2014) and further suggested Teachers' TPACK promotion path based on the collaborative knowledge construction ( $\mathrm{Wu}, 2017$ ).

Other Chinese researchers also advised the same idea of building collaborative TPACK learning communities, such as constructing community of teachers' professional learning (Zhang, Lin, \& He, 2015), improving cooperation community and sharing mechanism of teaching resources (Liu, Guo, \& Zhao, 2017), and developing rural teachers' TPACK by building teachers' learning community (Zhou \& Huang, 2016). With the continuous development of network and information technology, teachers' TPACK development model based on online practice community and online learning community were also put forward (Deng, 2015; Zhao \& Shen, 2019).

\section{3) Establishing and Improving Guarantee Mechanism}

The development of teachers' TPACK needed stable policies and measures (Xu, Fu, \& Hou, 2018). In order to promote the development of teachers' TPACK, it was necessary to form a diversified evaluation mechanism (Yan, Hui \& Ning, 2018), improve teaching resources sharing mechanism and promote the mutual aid mechanism of knowledge structure and subject development (Liu, Guo, \& Zhao, 2017; Li, 2017).

\subsubsection{Teachers' TPACK Study of Specific Subjects}

Research on teachers' TPACK of specific subjects has also become a hot topic in China. Teachers' TPACK Study must be combined with specific subjects (Duan, Yan, \& Zhang, 2015) because different subjects have different nature and content. Therefore, TPACK has different forms in different subjects (Jiao \& Zhong, 2010) and it would also be quite difficult to apply to specific subject matter courses.

We made a statistic analysis of the 169 journal papers of TPACK study in terms of different subjects. The statistical result was shown in Table 2.

After a deep content analysis of the 64 journal papers of specific subjects, we classified them into three domains. They are research on "TPACK frameworks of specific subjects", "particular applications of TPACK in specific subjects" and "development paths of teachers' TPACK of specific subjects".

\section{1) TPACK Frameworks of Specific Subjects}

Chinese researchers have carried out TPACK study in line with Chinese society and culture on the basis of foreign research results in order to find suitable ways to integrate TPACK. It was of great significance for teachers' TPACK development to make clear the concrete embodiment of TPACK in specific subjects (Yu, Bu, \& Zhang, 2014). Duan Yuanmei, Yan Zhiming and Zhang Kejun (2015) and Zhang Xinyan (2016) explored mathematics teachers' TPACK in middle schools through factor analysis. Lou Baiyu, Li Hongjuan and Ran Ming (2016) put forward Technological Pedagogical Chemistry Knowledge (TPCHK) 
Table 2. Teachers' TPACK study in specific subjects.

\begin{tabular}{cccccc}
\hline Subjects & Numbers & Subjects & Numbers & Subjects & Numbers \\
\hline Chinese & 1 & Physics & 5 & Biology & 2 \\
Mathematics & 16 & Chemistry & 12 & Science & 2 \\
$\begin{array}{c}\text { English } \\
\text { (Foreign Language) }\end{array}$ & 15 & Geography & 4 & $\begin{array}{c}\text { Information } \\
\text { Technology }\end{array}$ & 4 \\
Physical Education & 2 & Music & 1 & & \\
\hline
\end{tabular}

Notes: Because English is a foreign language in China, we used "English" and "Foreign Language" as key words to search in the topics of 169 journal papers. We got 13 journal papers. In addition, through content analysis of the 169 samples, we found another two papers were related to English subject. One was about Translation Course of English majors and the other was about British and American literature, so there were 15 journal papers relating to English subject together. By searching "Physics" in the topics of the samples, we got 6 journal papers, but we found one of the six belonged to science subject after content analysis though "Physics" was included in the topic. So there were 5 journal papers relating to Physics subject. By searching "Information and Technology" in the topics of the samples, we got 11 journal papers, but we found there were only 4 journal papers relating to Information and Technology subject after deep content analysis.

and its components. Ruan Quanyou (2014) advised Technological Strategic and Content Knowledge (TSACK) with reference to TPACK based on an EFL Teaching Project. Zhang Pengtao and Lynn Moorman (2018) suggested the transformation from G-TPCK to G-PCK. Chinese researchers have been carrying out study on TPACK frameworks of specific subjects according to the particular context where they teach.

\section{2) Particular Applications of TPACK in Specific Subjects}

"Integrating TPCK into specific subject area" was explained in detail in Handbook of Technological Pedagogical Content Knowledge (TPCK) for Educators (AACTE Committee on Innovation and Technology, 2008). Chinese teachers had carried out practical exploration of specific applications of TPACK in specific subjects in Chinese context. You Leilei (2018) demonstrated that TPACK could help teachers effectively by the use of various information technology and digital means to make concept teaching more vivid and efficient with the practical teaching example of "ion reaction". Huang Hua (2016) took the teaching practice of "vibration under external force" as an example and explored flipped classroom in physics in senior high school based on the TPACK framework. Li Mingxi (2018) also designed the construction dimension of College English learning cloud space based on TPACK.

\section{3) Development Paths of Specific Subjects Teachers' TPACK}

Chinese researchers in different subjects have also made some exploration and research on teachers' TPACK development paths with the consideration of the particularity of specific subjects. After a deep content analysis of the 64 journal papers which were related to teachers' TPACK of specific subjects, we found most development paths which were put forward in the 64 journal papers of TPACK study of specific subjects were similar to the former strategies which were suggested in the in-service teachers' TPACK development paths including promoting teachers autonomous development, building learning community and establishing and improving guarantee mechanism. 
Some researchers of specific subjects promoted teachers' autonomous development. Zhu Guiqin and Lu Qiang (2012) proposed to improve the reflective ability of Information and Technology Teachers in secondary schools, cultivate their autonomous development and develop their TPACK. Fan Lin and Zhang Xichun (2016) also advised English teachers should hold the concept of lifelong learning and pay attention to self-improvement of basic knowledge. Some researchers of specific subjects proposed building learning community. Li Yaying (2017) put forward the construction of TPACK development community for English teachers. Liu Yangyang and He Minxue (2018) also advised the establishment of TPACK learning community for PE Teachers. Some other researchers also suggested establishing and improving guarantee mechanism. For example, Zhu Hongcui (2017) advised constructing EFL-TPACK evaluation index system in middle school to ensure teachers' TPACK development.

Apart from the above three development paths, promoting teachers autonomous development, building learning community and establishing and improving guarantee mechanism, researchers of specific subjects also put forward improving the curriculum system of teacher education in specific subjects (Zhu, 2017; Li, 2017), strengthening and improving teacher training with specific subject content (Lin, Zheng, Ke, \& Lin, 2019; Zhu \& Lu, 2012).

The quantitative visual statistic analyses of the annual volume and the top five contribution institutions of TPACK journal papers offer the basic research overview of teachers TPACK development. The qualitative deep content analyses of such research themes as "Introduction of Foreign Study on Teachers' TPACK" "Pre-Service Teachers' TPACK Level and Development Paths" "Development Paths of In-Service Teachers' TPACK" "Teachers' TPACK Study of Specific Subjects", intends to show deeper analyses of teachers' TPACK study in China and offer references for researchers and educators in the field of teachers education.

\section{Conclusion}

This study provided a general review of the teachers' TPACK study in China. It showed that Chinese researchers have been interested in both pre-service and in-service teachers' TPACK development since TPACK was introduced to China in 2008. Although studies on TPACK development of both pre-service and in-service teachers, of specific subjects teachers have been carried on, there is still much room to explore in teachers' TPACK study in China like enhancing experimental or quasi-experimental research, developing in-service teachers' TPACK with consideration of particular contexts, cultivating pre-service teachers' TPACK with regards to different normal universities and subjects, promoting rural in-service teachers TPACK and deepening interactive reflection and negotiation community study to promote teachers' TPACK.

\section{Acknowledgements}

This paper is under the project of "The Research and Practice of Blending Teach- 
ing Competency of Higher Vocational College Teachers (No. SQ192022)" supported by Humanities and Social Science Research Project of Hebei Education Department. All the project members made their contributions to the paper.

\section{Conflicts of Interest}

The authors declare no conflicts of interest regarding the publication of this paper.

\section{References}

AACTE Committee on Innovation and Technology (2008). Handbook of Technological Pedagogical Content Knowledge (TPCK) for Educators. Routledge.

Bai, X. G. (2017). The Modal Construction and Path Selection of Teacher's TPACK Practice Teaching Capacity Cultivation. Heilongjiang Researches on Higher Education, 282, 108-112.

Cai, J. X., \& Deng, F. (2015). Research on Technological Pedagogical Content Knowledge (TPACK): Progress and Trends. Modern Distance Education Research, 135, 9-18.

Dai, J., Ren, Y., \& Li, W. (2018). Present Situation and Analysis of Pre-Service Biology Teachers TPACK. Biology Education, 43, 14-17.

Deng, F., Chen, L., Li, A., \& Wu, S. (2018). Pre-Service Chemistry Teachers' TPACK, Chemistry Epistemological Beliefs and Their Relationships. Chemistry Education, 39, 49-54.

Deng, G. (2015). Teachers TPACK Development Model Based on Online Ppractice Community. E-Education Research, 36, 109-114.

Deng, G., Li, H., \& Luo, M. (2018). Knowledge Mapping Analysis on English TPACK journal papers: Origin and Development. Distance Education in China, 413, 60-69.

Dong, Y., He, J., Sikandier, \& Xu, C. (2019). Technology Application Agency: The Source of Motivation for High School Teachers' TPACK Knowledge Enhancement. China Educational Technology, No. 10, 117-123.

Dong, Y., Sang, G., \& Cai, J. (2014). Difference and Profiles of Pre-Service Teachers' TPACK Knowledge. Teacher Education Research, 26, 36-43.

Duan, Y., Yan, Z., \& Zhang, K. (2015). TPACK Study on Junior Mathematics Teachers. E-education Research, 36, 114-120.

Fan, L., \& Zhang, X. (2016). English Teachers Professional Development on the Basis of TPACK. China Higher Education, No. 3, 76-79, 96.

Gu, Y., \& Qian, X. (2016). Research Status and Thinking of TPACK Measure Methods at Home and Abroad. Journal of Distance Education, 34, 97-104.

Hammerness, K. (2005). How Teachers Learn and Develop. Jossey Bass.

He, K. (2012a). TPACK - New Paths and Methods of American Integration between Curriculum and Technology. E-Education Research, 33, 5-10.

He, K. (2012b). TPACK - New Paths and Methods of American Integration between Curriculum and Technology. E-Education Research, 33, 47-56.

Huang, F. (2017a). The Construction, Significance and Enlightenment of Teachers' TPACK Learning Progressions that Web-Based Inquiry Science Environment. Primary \& Secondary Schooling Abroad, 211, 42-50.

Huang, F. (2017b). Reviews and Enlightenment of the American New Evaluation Tools on Teachers' Technological Pedagogical Content Knowledge. Studies in Foreign Edu- 
cation, 44, 36-50.

Huang, H. (2016). Flipped Classroom Teaching Practice of High School Physics in Perspective of TPACK. Modern Education Technology, 26, 77-83.

Huang, H. (2017). Research on TPACK Development of Pre-Service Science Teachers Based on Network Exploration Platform. Education Research Monthly, No. 2, 89-97.

Huang, L., Jiang, L., \& Zhang, C. (2017). Effectiveness of TPACK Game on Normal Students: Regulations of Teachers' Beliefs. E-Education Research, 38, 99-105.

Huang, X. (2018). Investigation on Pre-service Chemistry Teachers TPACK. Chemistry Education, 36, 44-49.

Jiao, J. L., \& Zhong, H. (2010). Research on Technology-Pedagogy-Content Knowledge (TPACK) and Its Development. Long Distance Education, 28, 39-45.

Kelly, P. (2006). What Is Teacher Learning? A Socio-Cultural Perspective. Oxford Review of Education, 32, 505-519. https://doi.org/10.1080/03054980600884227

Koehler, M. J., \& Mishra, P. (2005). What Happens When Teachers Design Educational Technology? The Development of Technological Pedagogical Content Knowledge. Journal of Educational Computing Research, 32, 131-152. https://doi.org/10.2190\%2F0EW7-01WB-BKHL-QDYV

Koehler, M. J., \& Mishra, P. (2008). Introducing TPCK. In AACTE Committee on Innovation and Technology (Ed.), Handbook of Technological Pedagogical Content Knowledge (TPCK) for Educators (pp. 3-29). Routledge.

Koehler, M. J., Mishra, P., Kereluik, K., Shin, T.S., \& Graham, C.R. (2014) The Technological Pedagogical Content Knowledge Framework. In J. M. Spector, M. Merrill, J. Elen, \& M. Bishop (Eds.), Handbook of Research on Educational Communications and Technology (pp. 101-111). Springer. https://doi.org/10.1007/978-1-4614-3185-5 9

Li, H. (2013). Study on Primary School Science Teaching in the Basis of TPACK. China Educational Technology, No. 11, 111-116.

Li, M. (2018). A Customized Learning Space based on TPACK and Its Applications for College English Teaching in Cloud Environments. China Educational Technology, 26, 77-83.

Li, Y. (2017). Construction and Development of English Teachers TPACK. Education and Management, No. 12, 65-67.

Lin, B., Zheng, J., Ke, X., \& Lin, Y. (2019). Construction of TPACK Training Curriculum of Secondary Physics Teacher. Education and Management, No. 3, 6-58.

Liu, L. (2019). Transformation of Teachers' Roles under the TPACK Framework. Theory and Practice of Education, 39, 39-42.

Liu, N., Guo, H., \& Zhao, J. (2017). Developing Adult Education Teachers Teaching Ability on the Basis of TPACK. China Adult Education, No. 19, 135-137.

Liu, Y., \& He, M. (2018). TPACK Structure and Generation of Physical Education Teachers: From Knowledge Field to Learning Community. Journal of Shenyang Sport University, 37, 113-117, 137.

Liu, Z. (2016). Pre-Service Teachers TPACK Study on the Basis of Empirical Analysis of SEM. Journal of Southwest China Normal University (Natural Science Edition), No. 4, 74-85.

Liuhuang, L., \& Huang, R. (2005). Interactive Study on CSCL. E-Education Research, No. 5, 9-13.

Lou, B., Li, H., \& Ran, M. (2016). Case Study of Technological Pedagogical Chemistry Knowledge under TPACK Perspective. Chemistry Education, 37, 53-58. 
Ma, J., \& Liu, Y. (2018). Development of Pre-Service Teachers TPACK-On the Basis of Micro-Courses. Distance Education in China, No. 3, 21-26.

Ministry of Education of the People's Republic of China (2012, March 13). The Ten Year Development Plan of Educational Informatization (2011-2020). 360 Encyclopedia. https://baike.so.com/doc/24826736-25758704.html

Ministry of Education of the People's Republic of China (2014, May 27). The Standard of Primary and Secondary School Teachers' Information Technology Application Ability (Trial Implementation). 360 Encyclopedia. https://baike.so.com/doc/9774162-10120837.html

Nie, X. (2017). Study on Construction of Waterfall Model for Pre-Service Teachers' TPACK Capacity Building: Taking Mathematics as an Example. E-Education Research, $38,122-128$.

Ning, L., \& Xiang, K. (2015). Study on Current Situation and Development Trend of Teachers TPACK. Educational Research and Experiment, 157, 31-35, 80.

Ruan, Q. (2014). TPACK and TSACK in Flipped Classroom: A Discussion Based on an EFL Teaching Project. Distance Education Journal, 32, 58-66.

Ruan, Q., \& Yang, Y. (2014). Development of Technological Pedagogical and Content Knowledge: Development of Technological Pedagogical and Content Knowledge: From TPACK to TSACK to TMACK. Distance Education in China, No. 11, 20-26, 96.

Shang, L., \& Cheng, C. (2017). Study on Physical Education Teachers TPACK. Journal of Physical Culture, No. 7, 124-129.

Shu, X. (2014). Research on Teachers' Professional Development Based on TPACK Framework-From Assistance in Teaching to Normalization in Curriculum Integration. Technology Enhanced Foreign Language Education, No. 1, 58-64.

Shulman, L. S. (1987). Knowledge and Teaching: Foundation of New Reform. Harvard Educational Review, 57, 1-23. https://doi.org/10.17763/haer.57.1.j463w79r56455411

Shulman, L. S. (2004). How and What Teacher Learn: A Shifting Perspective. Curriculum Studies, 36, 257-271. https://doi.org/10.1080/0022027032000148298

Shulman. L. S. (1986). Those Who Understand: Knowledge Growth in Teaching. Educational Researcher, 15, 4-14. https://doi.org/10.3102\%2F0013189X015002004

The Central Committee of the Communist Party of China and the State Council (2018, January 20). The Opinions on Comprehensively Deepening the Reform of the Construction of Teachers in the New Era. 360 Encyclopedia. https://baike.so.com/doc/27073921-28457608.html

The Central Committee of the Communist Party of China and the State Council (2019, February 24). Educational Modernization of China 2035. 360 Encyclopedia. https://baike.so.com/doc/28625203-30085497.html

Wang, C., \& Wu, F. (2018). Performance Analysis and Improvement Path of Pre-Service Teachers' TPACK Level. Modern Distance Education, 176, 62-71.

Wang, L., \& Fu, L. (2015). TPACK Present Situation Investigation on Pre-Service Chemistry Teachers in the Local Normal Universities. Modern Education Technology, 25, 78-84.

Wei, Z., \& Zhou, Q. (2015). Investigation and Analysis on TPCK in the Core of Pre-Service Teachers' TPACK: In the Pre-Service Chemistry Teachers as an Example. Global Education, 44, 74-84.

$\mathrm{Wu}, \mathrm{H}$. (2014). Inspiration of Foreign Teachers TPACK Development Paths. Modern Educational Technology, 24, 51-57.

Wu, H. (2017). Research on Teachers' TPACK Promotion Path Based on Collaborative 
Knowledge Construction: A Design-Based Research. E-Education Research, 38, 118-123.

Wu, H., Yu, S., \& Ma, N. (2014). Study on the Construct of Collaborative Construction Model for Development of Teacher's TPACK. China Educational Technology, No. 9, 111-119.

Xie, Y., Song, N., \& Liu, M. (2008). Study on Collaborative Knowledge Building and the Community on the Basis of Internet. E-Education Research, No. 4, 38-46.

$\mathrm{Xu}, \mathrm{C} ., \mathrm{Fu}, \mathrm{G} ., \mathrm{H}$ Hou, X. (2018). The Study of Teacher's TPACK Levels and Development Strategy in Universities. Modern Education Technology, 28, 59-65.

Xu, P., Liu, Y., Wang, Y., \& Zhang, H. (2013). Reviews and Enlightenment of Foreign Measurement on Technological Pedagogical Content Knowledge. E-Education Research, 34, 98-101.

Xu, P., Zhang, H., Wang, Y., \& Liu, Y. (2013). Foreign TPACK Study and Enlightenment. China Educational Technology, 320, 112-116.

Yan, B., Hui, Q., \& Ning, L. (2018). Comparative Study on Urban and Rural Junior Secondary School Mathematics Teachers TPACK. Shanghai Education Science, No. 6, 51-56.

You, L. (2018). Study on Electrolyte Concept Teaching Based on TPACK Framework. Chemistry Teaching, No. 12, 45-50.

Yu, Y., Bu, J., \& Zhang, H. (2014). Challenges Facing TPACK Theoretical Research. China Educational Technology, 328, 20-25.

Yuan, Z. (2012). Literature Review on Technological Pedagogical Content Knowledge. Journal of Mathematics Education, 21, 13-18.

Zhan, Y., \& Ren, Y. (2011). An experimental study on the training of Pre-Service Mathematics Teachers. China Educational Technology, 297, 15-23.

Zhang, B., \& Zhang, J. (2013). TPACK Latest Understanding about ICT for Subject Teaching and Learning: An Interview with Professor Matthew Koehler. Open Education Research, 19, 4-11.

Zhang, F., Lin, J., \& He, S. (2015). Research on the Characteristics and Development of College English Teachers' TPACK. China Educational Technology, No. 5, 124-129.

Zhang, J., \& Liu, G. (2015). Development Mechanism and Cultivation Path of Teachers' TPACK from Multi-dimensional Perspectives. Journal of Distance Education, 33, 95-102.

Zhang, J., \& Yang, W. (2016). Analysis and Reconstruction of Pre-Service Teachers Education Curriculum System for TPACK Development. Theory and Practice of Education, 36, 41-44.

Zhang, P., \& Lynn, M. (2018). Enlightment of SMAR Model and G-TPCK Framework to the Application of Geography Educational Technology. Geography Teaching, No. 21, 4-10.

Zhang, T., \& Wang, L. (2016). The Investigation of Teacher Education Students' TPACK-A Case Study on Mathematics Teacher Education Students. Journal of Southwest China Normal University (Natural Science Edition), 41, 221-225.

Zhang, X. (2016). Exploring the Factor of Mathematics Teachers' Technological Pedagogical Content Knowledge in Middle School. Journal of Mathematics Education, 36, $114-120$

Zhang, Z., Zhang, H., Liu, J., \& Wang, Y. (2015). A Research on Pre-Service Teachers' Technological Pedagogical Content Knowledge Structure: Based on Empirical Analysis of SEM. China Educational Technology, No. 8, 103-109. 
Zhao, X., \& Shen, S. (2019). The Construction Strategy of Teachers' TPACK Tower Cognitive Hierarchy in Online Education. Modern Distance Education, No. 3, 49-55.

Zheng, Z., \& Zhang, G. (2019). Practical Research of Pre-Service Teachers' TPACK Development Based on Design-Based. China Educational Technology, 389, 86-94.

Zhou, L., \& Huang, D. (2016). Study on Rural Teachers TPACK Development on the Basis of Teaching Process. The In-Service Education and Training of School Teachers, No. 8, 9-13.

Zhu, G., \& Lu, Q. (2012). Investigation and Development Paths of Information and Technology Teachers' TPACK in Secondary Schools. China Educational Technology, No. 12, 59-65.

Zhu, H. (2017). A Study on EFL-TPACK Literacy of Middle School English Teachers: Insights from the Lesson Analysis of Junior High School English Teaching Demonstration Seminar in Jiangsu Province in 2015. Journal of Schooling Studies, 14, 78-85. 